\title{
Feminist Space Invaders: Killjoy Conversations in Neoliberal Universities
}

\author{
by Carrie E. Hart and Sarah E. Colonna
}

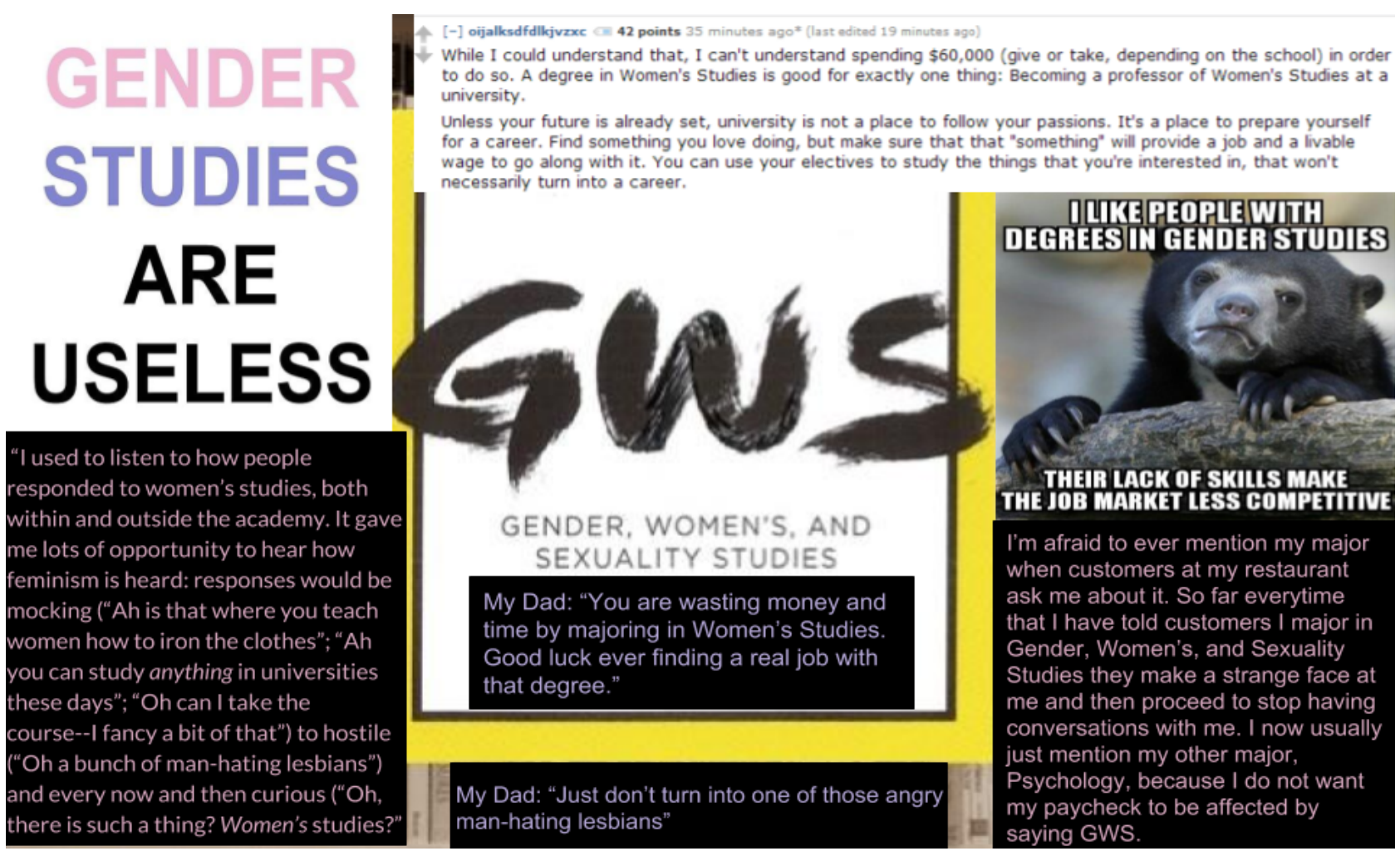

COLLAGE BY FEMINIST THEORIES STUDENT. IMAGE COURTESY OF AUTHORS 
Living a feminist life does not mean adopting a set of ideas or norms of conduct, although it might mean asking ethical questions about how to live better in an unjust and unequal world (in a non-feminist and antifeminist world); how to create relationships with others that are more equal; how to find ways to support those who are not supported or who are less supported by social systems; how to keep coming up against histories that have become concrete, histories that have become as solid as walls.

\section{- $\quad$ Sara Ahmed, Living a Feminist Life}

W hat does it mean to live a feminist life as a teacher or student? What practices, commitments, and conversations can unfold through an exploration of feminism as a part of formal curriculum? As teachers of Gender, Women's, and Sexuality Studies (GWS), we imagine our classrooms as spaces in which students can not only learn about what feminism means, but can also directly participate in feminism as a process that actively addresses the unjust systems we learn about together. The strategies we employ, and the ways in which we invite students to imagine what could be, are meant to expand our collective agency, courage, and creativity in the interests of transforming oppressive practices in formal schooling and beyond.

During the 2019 spring semester, we both taught sections of upper-level undergraduate feminist theory courses at two mid-sized public universities in the Southeastern United States. University A was chartered as a coeducational teacher training school for rural, mountain students and this regional location is still a large part of its identity today. University $A$ is a predominantly White institution (PWI) with $82.6 \%$ white students, $45 \%$ male and $55 \%$ female (with no numbers on trans or nonbinary students). Low-income students make up $27 \%$ of the student body, with $30 \%$ identified as rural students and $28 \%$ as first-generation college students. University B was chartered as a normal school for women, which became coeducational in the 1960s. University B currently meets the definition of a minority-serving institution (MSI) with the 2015 undergraduate student body consisting of approximately $27 \%$ Black students and $7 \%$ Latinx students, $76 \%$ female and $24 \%$ male (with no numbers for trans or gender nonbinary students). University B draws $58 \%$ of its student body from a 5-county pool, including three of the state's largest cities. University B is designated a Title III school with $1 / 3$ of undergraduates identified as firstgeneration college students and $45 \%$ identified as lowincome students.

As an experiment in feminist pedagogy, we facilitated an ongoing, asynchronous conversation between our two classes over the course of the semester. Being mindful of the ways in which pedagogical experimentation can sometimes create an additional workload, we wanted to pursue this ongoing dialogue in a way that enhanced the overall learning experience without adding too much additional work for either us or our students. Since our classes met at different times on geographically distant campuses, what we settled on was creating a Google document (template below) that was shared between our classes and editable by everyone. Within that document, we created a template where there was space for each class to "forecast" questions and ideas about that day's assigned material, a "recap" where the ideas of the class could be reflected upon, and a "response" section where the sister class could respond back to any questions posed or ideas raised. We incorporated the responsibility of filling out this template to the student who was the designated student facilitator for that class.

\section{WGS SHARED GOOGLE DOCUMENT EXAMPLE}

\begin{tabular}{|l|l|}
\hline $\begin{array}{l}\text { Discussant/ } \\
\text { Facilitator }\end{array}$ & Your name goes here. \\
\hline Forecast & $\begin{array}{l}\text { This is where you will briefly describe } \\
\text { your plans for facilitating discussion } \\
\text { during class. Is there a particular } \\
\text { question or concept you will be exploring? } \\
\text { What do you want your sister class to } \\
\text { know about how you will be using class } \\
\text { today? }\end{array}$ \\
\hline Recap & $\begin{array}{l}\text { An idea, question, or theme that you } \\
\text { want to pose to the other class based on } \\
\text { what you learned that day } \\
\text { What connections to feminist theory/lived } \\
\text { experiences are you making? }\end{array}$ \\
\hline $\begin{array}{l}\text { Sister class } \\
\text { responds }\end{array}$ & \\
\hline
\end{tabular}

During our initial class meetings, we made each of our classes aware of the existence of their sister class and explained that we would be dialoguing throughout the semester in written form. Our goal in doing this was to generate some awareness of what the other class was working on and to highlight that the concepts we were discussing could be taken up in various ways. The rhythm we developed for our classes was that either the teacher or the student facilitator would pull an idea out of the document and connect it to our readings/discussion or find a question the sister class had posed and use that question to begin class. This ongoing practice let students see the work the other class was doing and also served as a reminder that the conversation was bigger than either group by itself.

In addition to hopefully enhancing the learning in each classroom by bringing our students together, we were also interested in collaborating in this way as a form of "space invasion" -- a concept that Ahmed (2017) and Puwar (2004) use to describe the irreverent, subversive, and scrappy methods by which marginalized groups can enter institutions and take up space even when patterns and practices of 
dominance attempt to exclude them. Ahmed (2017) posits that feminists "can be space invaders in the academy" by asking uncomfortable questions about educational institutions and by noticing how they reward whiteness and maleness at the expense of other groups (p. 9). Our goal in connecting our students with each other was to help them notice and affirm the ways in which they, individually, and we, collectively, can operate as space invaders in institutions of higher education. By undertaking this experiment, we wanted to show ourselves and our students a pedagogy that works against the grain. By intentionally sharing, but also invading, each other's spaces, we challenged the synchronous, spatially-bounded, and institutionally singular qualities that each of our sections had built into their official descriptions and the unofficial assumptions that come along with what teaching "should" involve.

\section{Who We Are}

As context for understanding what made this collaborative pedagogy possible, it is helpful to know that both authors have known and worked with each other in academic and community settings for almost 10 years. We attended the same graduate programs and have taught similar classes at various colleges, universities, high schools, and summer programs. We have been on conference panels together and have been involved with LGBTQ+ youth activism in our communities. We occupy some similar privileges (e.g. whiteness, a middle-class upbringing) and experiences (e.g. growing up in the Southeastern US) and some differences (e.g. sexuality).

When we discovered that we were both teaching upperlevel Feminist Theory for the first time, we met to share ideas, compare syllabi, and reflect on what we might encounter in our respective classes. During this conversation, we imagined "what if": what if we taught together, what if our classes knew that students at another campus were grappling with the same ideas they were, and what if we were able to "pull back the curtain" to see how other students were learning and making connections with similar material. We began to explore the possibility of facilitating conversation between our students. From the beginning, our goal was to broaden the discussions that each of our classes were having on their own, but also to explore and demonstrate feminist praxis as a conversation between groups sometimes separated by experiences, spatial locations, and institutions. Independently, we had both decided to include Sara Ahmed's (2017) Living a Feminist Life as a primary text in our classes, so our course schedules bore some similarities to one another. At the same time, there were also significant differences between our classes in terms of the texts that we read and when we read them. Even in each of our classes' discussions of Ahmed's work, there was never a time that they were reading the exact same chapter on the exact same day, so we knew that there would be many asynchronous dimensions to the interactions between our classes. The University B class was scheduled for Tuesdays and Thursdays from 2-3:15 pm and University A met directly after from $3: 30-4: 45$ on our respective campuses. As these scheduling details had been set before we knew of our collaboration, we did our best to work with the institutional parameters in place. We wondered -- if our classes couldn't speak with one another in person or even synchronously, couldn't there still be a way for us to be in conversation, and for us to view that dialogue as a way to work critically with what we had been given?

Most of this experiment was about our students and our pedagogy, but some of it was about us. So often, teaching seems a lonesome experience in which we are supposed to "know" rather than try. Teachers are positioned as experts within their classrooms, but we wondered how we might be able to critique expectations around expertise by being intentional about learning and trying new things. As we prepared to begin the semester, we wondered what would happen if we, as teachers and academics, connected with each other as we taught a new class; served as a sounding board, if needed; and supported one another through each of our experiences teaching classes that were new to us. We followed advice set out by bell hooks (1994) that it is "crucial that critical thinkers who want to change our teaching practices talk to one another, collaborate in a discussion that crosses boundaries and creates a space for intervention" ( $p$. 129). Though hooks's mid-1990s essay was not talking about a shared Google document, this document project created a new kind of space both in our respective institutions and also between them. Within and through it, we explored new ways of connecting, collaborating, and learning with and from one another. As teachers teaching feminist theory, but both being contingent to our academic departments, we need and value each other's support and feedback. It is often easier, and more politically salient, to stick with tried and true pedagogy. To try something new is a change and change involves risk, bringing up questions like, "What if it doesn't work?" and "What if students don't engage with the new format?" Having a colleague there to bounce ideas around and to say "let's just experiment for this semester" made this hard work more manageable, and we imagine it could do so for other teachers as well.

\section{Feminist Conversation, Feminist Community}

The reason we brought our classes into this kind of extended conversation with each other is inspired by a sense of collectivity that feminists have often pursued -- the idea being that feminists can understand patriarchy better when they listen to one another across a range of experiences with oppression, and that strategies that take this deep listening into account will be that much smarter and more complex. As Lorde (1984) famously wrote in her remarks to the primarily white feminist organizers of the Second Sex Conference in 1979, "As women, we have been taught either to ignore our differences, or to view them as causes for separation and suspicion rather than as forces for change... Community must not mean a shedding of our differences, nor the pathetic pretense that these differences do not exist" (p. 112). Students in Gender, Women's, and Sexuality Studies classes of the late 2010's often read about the concepts Lorde references; in bringing our classes together, we were interested in how our students would entertain and grapple with the differences within and between the two groups, and we were hopeful that an ongoing conversation 
between our classes would give them practice with being in community with another group exploring similar ideas, albeit from different personal and institutional locations. We wondered -- what different interpretations of feminist theory might students at a predominately white institution and a minority-serving institution entertain about themselves, and about each other? In what ways would our students bring new insights about the feminist theory we were exploring into each other's awarenesses?

Throughout the course of our time together, we encouraged our students to reflect on how some of the differences they encountered with each other were mediated by, within, and between their two institutions. In reflecting on this experience of teaching and learning in conversation with each other, we were interested in how this experience of collectivity highlighted difference, gave our students opportunities to become more aware of the ways institutions of higher education operate, and highlighted opportunities for feminist teachers and students to be scrappy and innovative, not in the interest of increasing the educational marketability, but because feminist dialogue is often much richer when we do.

Early on in the semester, a conversation came up between our classes that revolved around the difference between the two universities, particularly regarding the racial demographics of each university as a whole. University B's class posed the questions "How do we practice theory? Is it possible to practice intersectionality?" A few classes later, after each class had chimed in with general thoughts about how Crenshaw's (1989) concept of intersectionality helps them to think about oppression as layered and overlapping, University B then asked the institutionally-specific question, "How do you, at [University A], implement intersectionality in your lives at a predominantly white institution?" Author A's class responded with discomfort, but also acknowledged the accuracy of the assessment of their institution as deeply informed by whiteness. What followed was a genuine and honest classroom discussion about whiteness at University $A$ and how GWS classes need to contend with it, as well as how GWS classes might give students opportunities and tools for better challenging whiteness as a form of institutional dominance. Several students of color in class spoke to how whiteness impacted them at the institution, and white students listened and affirmed these experiences. Ultimately, the class crafted this response to share with University B:

It is uncomfortable to acknowledge this reality at our school. Being aware of broader systems and also social practices that produce exclusion is possible. Try to be aware of our privileges, don't tokenize people, and be aware of the space we're taking up. Be really intentional about listening to voices of color both in person and in the authors we are reading in our classes. Be aware of admissions data and ask questions about the trends presented there. Thinking also about the local history of [the location of University A] and how that may be hostile to people of color.
That this conversation resulted from dialogue between a PWI and a more racially diverse institution demonstrates the difficulty and importance of grappling with difference openly and honestly. Even later on in the semester, the question about institutional whiteness and the discomfort it raised seemed to linger for many of the University A students, demonstrating the ways in which feminist community can be challenging and possibly contentious, even as it is also connective and potentially supportive. To Author $A$, the quality of this conversation took on an especially meaningful tone because University A's institutional whiteness was raised by an "outside" group. The directness of University B's question prompted University A's class to articulate the specific forms of action available to them within and perhaps despite the institution. It is one thing for a group of students to acknowledge their own institution's whiteness (and, for students of color, to experience this force daily) -- it is another thing for an outside group to say that they notice the whiteness of your institution and hold you accountable for speaking on it.

\section{Feminist Killjoys in the Neoliberal University}

Our approaches to teaching these courses collaboratively were informed by the pervasive way in which neoliberal politics have infused higher education. Our commitment to working together was fueled in part by a spirit of resistance to the conditions that neoliberalism breeds, and it was our objective to help explore these strategies for resistance and reimagining with and alongside our students. To be clear about our own understandings of neoliberalism in higher education, we refer to Griffey's (2019) explanation that "The neoliberal university (or college) is an institution of higher education whose governance is primarily organized around increasing revenue, even when it is a non-profit or public institution. All other functions are secondary." This overall commitment to profit produces a way of understanding education as an experience that is marketed to students as a commodity and in which students are understood as consumers of an overall experience that increasingly prioritizes facilities and a branded identity over actual teaching and learning. In the big picture, the neoliberal university is one in which the main purpose is to generate profit, and in which capitalist values of individualistic competition are infused throughout the discourse about the purpose and process of higher education. This paradigm positions the university experience as a series of commodities available for individual students to consume, which understandably warps the role of education in posing challenging questions, helping students to become critical thinkers, and providing communities with nuanced ways to understand their members. Professors might feel the pressure of neoliberalism in the form of increased class sizes, stagnating salaries and/or other forms of precarity, directives to produce and position scholarship in competitive ways, student anxiety about whether and how their studies are applicable to employment opportunities, and the common understanding of a degree as a commodity earned and then exchanged for a job after graduation (Canella, G. \& Koro- 
Ljungberg, M., 2017 \& Saunders, D. B. \& Blanco Ramirez, G., 2017).

In Gender, Women's, \& Sexuality Studies, there is often pressure on already overworked faculty to increase the number of majors in order to prove program legitimacy to governing structures within the university. Students themselves encounter pressures from their families or relationships outside of GWS to major in a subject more legibly tied to profitable jobs. As one class explained to another about mid-way through the semester:

Many of our peers reported moments of being constantly questioned when bringing up that they're studying GWS because of myths that it's an "easy" subject or because others don't believe/don't know you can do anything with a GWS degree. For y'all: Why is there such an emphasis in our society to study subjects that lead to a "good career"?

The refrain of "Women's Studies? What are you going to do with that?" is commonly levied against our students, and our students drew attention to this question and the discourse that supports it as itself an expression of power. They also invited each other to commiserate in the experience of enduring this frequent line of questioning -- a move that we see as enabled by the feminist community they were participating in with each other. Though many of our students already had the ability to identify anti-feminist thought before they came into our classes, being able to share their observations with each other and trace their experiences as part of a larger pattern is a crucial reason for building feminist community.

Though neoliberalism is pervasive, is it not always understood as an interconnected system with identifiable patterns and effects. As we see it, developing a robust ability

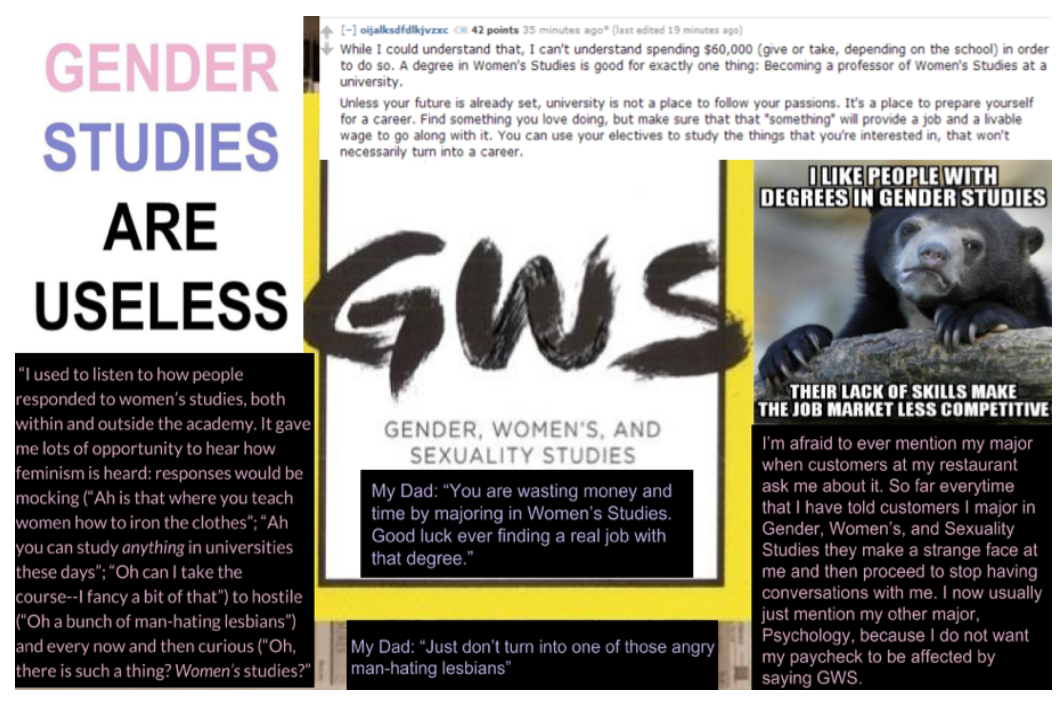

COLLAGE BY FEMINIST THEORIES STUDENT. IMAGE COURTESY OF AUTHORS

to observe, critique, and re-imagine institutions is fundamental to feminist pedagogy. When our students shared observations with each other about the dearth of GWS classes at each of their schools, they were able to start tracing a larger picture of how resources are (or are not) allotted and how that shapes the climate of higher education. Together, they imagined how each of their schools would be different if there were more GWS classes, or even more classes that centered feminist inquiry. In response to an exercise in one class in which students considered what life would be like on an entirely feminist planet, the other class brainstormed components of their ideal feminist university. They shared the following image:

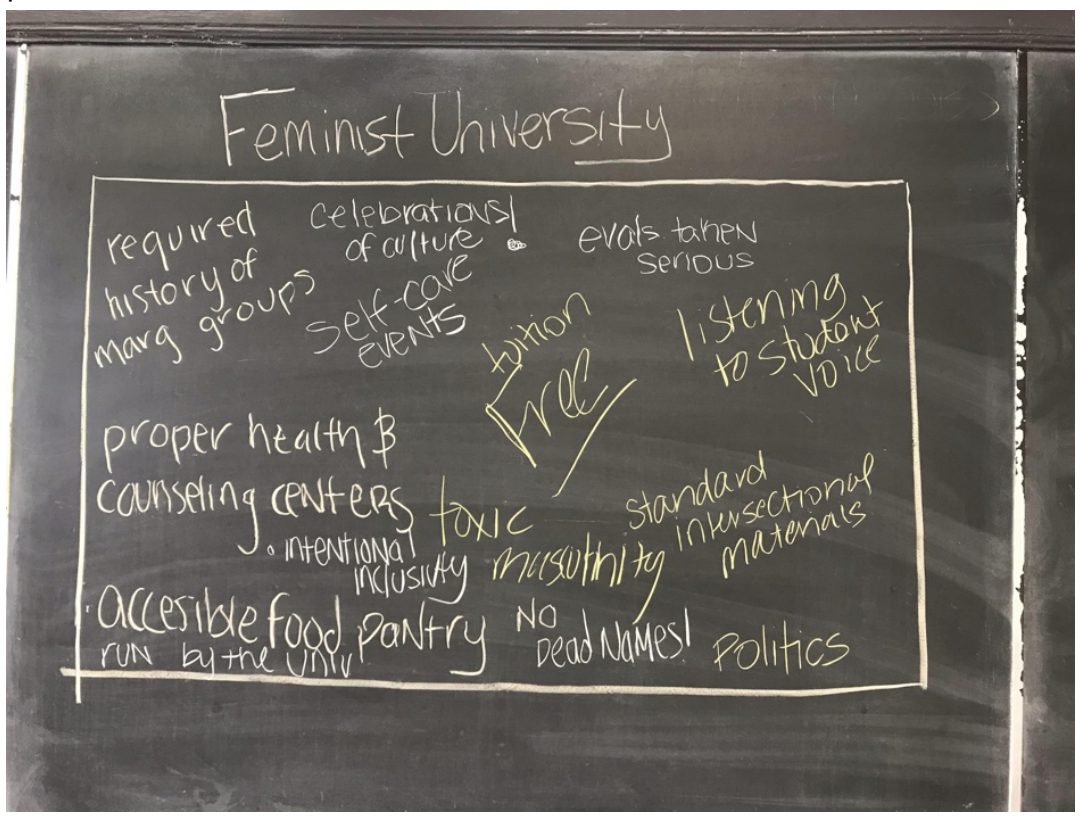

Author A's class responded by adding several other suggestions for what their idea of a feminist university would involve, including:

No buildings named after people at all, more accessibility in general, self-care centers with a nap area, equal funding for all programs (stop hyper-funding sports), more breastfeeding/pumping accessible spaces, free menstrual products everywhere, and the possible end to tenure (a suggestion that horrified Author A but that was compelling nonetheless).

This collective exercise not only required students to begin to imagine alternatives, but also to articulate what exactly was unjust about the university settings they inhabit. For many students, this exercise came easily. While the work needed to actualize some of these suggestions is substantial and would require considerable organization, imagining and articulating these changes is the beginning of those efforts, and can signal a crucial refusal to accept a harmful status quo. As Anzaldúa (1987) writes, ""Nothing happens in the 'real' world unless it first happens in the images in our heads" (p. 109).

By being in dialogue and community with one another, our students were able to share in some of their own observations and experiences within their respective institutions of higher ed; additionally, they began to share 
strategies with each other of how to operate bravely, subversively, and confidently in their roles as students. One class wrote the following summary of their class discussion in the shared document:

We talked about personal experiences of speaking up in non-GWS classes and either getting steamrolled or worrying about whether the prof would deduct points off of our grades. We also mentioned that sometimes especially in this situation, it is important to say something. Since [our school] is so predominately white, it can be even more dangerous for people of color to speak up. This connects to being dismissed as "the angry black woman." ... At the same time, sometimes we felt it isn't always as dangerous as it seems to talk about feminism in other contexts -- sometimes you just have to do it.

In Ahmed's (2017) Living a Feminist Live, the text that both classes read and discussed the most extensively throughout the semester, Ahmed writes about the feminist killjoy as a figure who not only notices the wrongs produced by sexism, racism, and other overlapping oppressions but also refuses to let them slide. In many cases, this means acting in ways that people perceive to be joy-killing -- by naming the joke as sexist, by identifying the racism in the conversation, by calling for institutions to change. As Ahmed and our students both discussed, being a feminist killjoy is hard and sometimes isolating work. Just as Ahmed includes other killjoys in her own feminist survival kit, our students too had the opportunity and experience to connect with each other as a group of killjoys -- a killjoy community across and despite institutional barriers (p. 244).

Since neoliberalism enshrines the individual as the most important social unit and efficiency as a desirable quality, our collaboration challenged both the idea that students, even feminist ones, ultimately should or do work in isolation from one another. Each time we "pulled back the curtain" to see what the other class had been discussing, we were able to explore the very real conversations that were happening in another space and think about how the discussions in our classes related. By setting up the learning environment in this way, we very intentionally resisted collapsing the two courses into one (as is sometimes the model of efficiency presented in inter-campus programs collaborations). Our collaboration wasn't part of the marketing for our classes or the universities; rather, we created it because we thought it would be helpful to us and our students, and because it makes logical sense in the tradition of feminists establishing critical communities with each other. Ahmed (2017) writes that "feminism is bringing people into the room" (p. 3). With the resources available to us, we took that directive seriously by invading each other's spaces and bringing our sister classes into each other's rooms. While this dialogue was challenging at times, our students also spoke to how it was beneficial to their thinking -- that hearing another group's interpretation of shared texts often revealed new insights for them each to consider.

In many ways, our pedagogical choices pushed our students to think about what it means to employ feminism in all dimensions and experiences of their lives, including as university students. This not only challenges the idea that feminist theory is something that happens within school as merely a thought exercise to be applied later in the "actual" action, but that school itself is a depoliticized location. By connecting our classes, we hoped to push our students to consider how and in what ways they are sometimes encouraged to be disconnected within their learning processes, as well as to whom and under what conditions they are encouraged to connect with others as feminists and/or as students. Saunders \& Blanco Ramirez (2017) argue that one of the effects of neoliberalism within education is a commodification of the educational experience in which students are understood as passive "recipients of an ossified education that is represented by their resume and academic credentials [rather than] active (co)creators of their educational experiences, which cannot be fully captured by a resume or reduced to a diploma" (p. 191). In $f$ acilitating dialogue between our classes, we hoped to push back on this passive, commodified experience of education by treating the conversations of the other class as a legitimate and living text -- one in which the ideas explored were not necessarily easily or ever resolved but instead continued to warrant active exploration.

\section{Feminist Pedagogy as Sweaty Concept}

In order to participate meaningfully in feminist thinking, writing, and movements, students need to have some sense of what institutions are and how they work. They need to be able to give themselves permission to notice the institutions that house them, as well as how those structures restrict and impact their experiences and how they might, through various tactics and actions, find the weak spots in those structures in order to alter them. We wanted to collaborate, in part, as an exercise in connection with one another, and also because of the ways in which doing so would expose our students to a re-imagining of what education can involve. For many students, feminism offers a new way of looking at the world, which Ahmed describes as a "reorientation to the world, a different slant on the same thing" (p. 13). While classroom cultures are often confined to the students and the teacher in the room (and the conversation they are having with scholars in the discipline in which they are studying), we opened up conversation between our classes so our students could be aware, in a concrete way, of conversations that other students were having with and about feminist ways of thinking. In regularly considering what the other class was discussing, we fought against the sense of isolation that students can sometimes experience when pursuing feminist thinking both within and beyond educational institutions. Which was an important consideration as both of our courses were taking place at mid-sized public universities with over 15,000 enrolled undergraduate students. These courses were among the few, if not the only, feminist theory courses offered during the semester we have described.

Feminist community involves seeking out and listening to others who are entertaining similar questions, but who are not necessarily on the exact same page, space, or time. It can certainly still be a valuable exercise for students to have an in-depth conversation about a singular text that they have all read and considered for any given class period; 
however, pursuing this pedagogical choice exclusively can set students up for confusion, frustration, and defeat when they are in positions of needing to converse across a range of ideas, vocabularies, and experiences. For reasons that we both did and did not have control over, we did not align our classes precisely. They shared some but not all texts, and even for the shared texts, they did not read them at the same time. The conversations we opened up between the two groups were asynchronous both in terms of time and also content. This choice had to do with working with what we had, but also pushing our students to think experimentally about how it is possible to work with what is available, and how conversations do not have to occur exactly in synch with one another in order to further the learning and action that feminist frameworks can support. This is an unconventional way to work, but perhaps not so surprising when one thinks about the ways in which women and other marginalized groups have often had to be scrappy and experimental in their pursuit of justice.

Ahmed (2017) describes concepts as "sweaty" when they are sticky and also when they involve active work and working through. She writes that sweaty concepts "have questions that surround them... [Sweaty questions] are difficult questions, and our task is not to resolve them; they are life questions" (Ahmed, 2017, p. 195). We are reminded of our class's conversation about intersectionality that emerged early in the semester and popped up at various points throughout the rest of our time with these students. Following the observations each group made about the racial diversity of their own and each other's institutions, they each posed questions about their personal relationships to those demographics. University A asked, "Did you purposefully consider the diversity of [your school] when you decided to attend there?" -- to which University B replied that many of them did, and that this was an important factor in their decision to enroll. They also posed the question, "Did you consider the lack of diversity when considering [your school]?" For students at University A, this was a sweaty question. It did not seem like they anticipated it, but when posed with responding, they met the task with dedication and focus. Ultimately, they composed this response:

Some of us did consider the lack of (racial, gender, and sexuality, socioeconomic, religious) diversity, while others did not. It feels uncomfortable but also important to be called on that. We talked about the institutional whiteness of this institution, and how it is historical and geographical and how some of us felt compelled to try to address that personally through our attendance here, while others didn't have to think about it when deciding where to go. We also talked about the way in which admissions marketing over-represents racial and also queer diversity. We are left with questions for ourselves about what to do.

These qualities of determination and uncertainty are central to feminist work. When faced with the injustices that oppressive systems perpetrate, what are feminists to do? Sometimes the answers are clear, and sometimes they can be made clearer by dialogue with others who have different experiences. As Lorde (1984) explains, "In a world of possibility for us all, our personal visions help lay the groundwork for political action... divide and conquer must become define and empower" (p. 112). By working together, by posing uncomfortable questions, and by listening to each other's ideas, feminists in community across difference can both learn and continue to do the complex, challenging work of taking anti-oppressive action.

The collaboration between our classes provided another dimension through which to pose questions, and also in which to observe questions being posed. The regular checkins with the other class provided brief glimpses into the ways that others were working through the sweaty issues that feminist theory can raise about institutions and the way that individuals and collectives can both navigate and challenge them. These glimpses were not comprehensive -- there was no way for either class to know exactly what had been read or said or thought by all of the members of the other class, and this was part of the intrigue of the exercise -- because that is how feminist scholarship, activism, and conversation often operates -- in glimpses and snippets, building over time, but also sometimes dropping lines of thought, misunderstanding or mischaracterizing what has been suggested or done. Despite the messiness of building intellectual communities, people do still participate in and craft those communities, and when they do so in collaboration with others, new and potentially liberating possibilities can arise.

\section{Conclusion}

Establishing that there was a Feminist Theory class on another campus with similar goals was a strategic move on our part -- in conversing regularly, we wanted to prompt students to think beyond the boundaries of their own class. We wanted them up to know that, for better or worse, they are not alone in the practice of feminist theorizing, and that conversing with other feminist students across space and time can make learning richer. In pursuing this experiment, we wanted to show students that they too have the agency, skills, knowledge, and ability to do things differently in order to make education and the world around them work for them instead of passively consuming the status quo.

In reflecting on our pedagogical experiment, we find it valuable to highlight the creativity with which it is possible to approach institutions. The demolition of oppressions that live within and are enabled by larger structures requires an understanding of not only the structures themselves, but also their blind spots and the ways in which they can be strategically weakened. In employing these space invading strategies within our teaching, we asked ourselves what could be possible not because it was a requirement or an endorsement from our universities, but because as teachers and students of feminism, we recognize the value of conversing with those beyond the boundaries of any given class, program, or discipline.

\section{RADICALTEACHER}




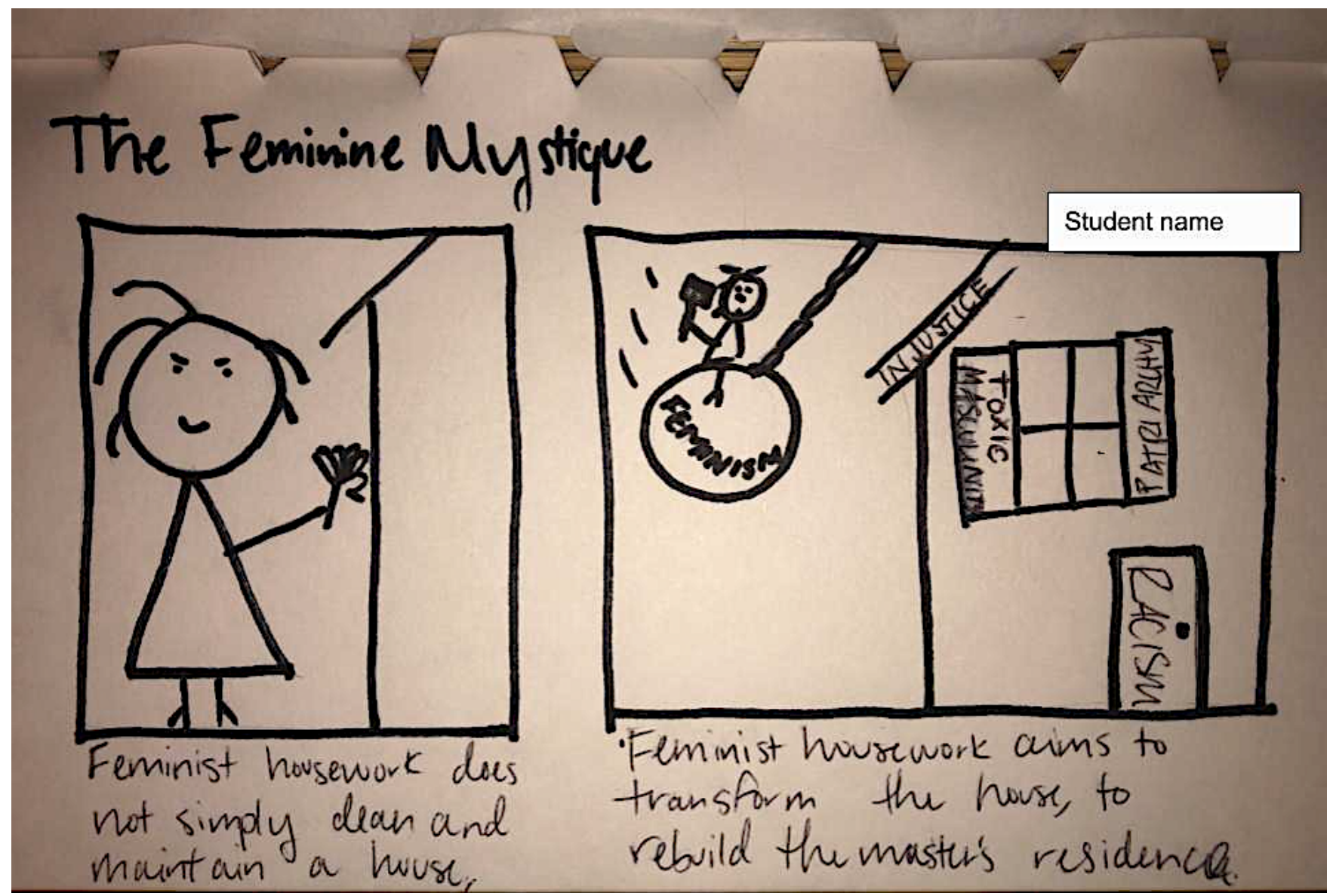

ORIGINAL ILLUSTRATION BY FEMINIST THEORIES STUDENT 3. IMAGE COURTESY OF AUTHORS

Raising questions about institutions from within them can be tricky, delicate work, but as teachers of feminist thought, we find it crucial to do. When we model ways to work strategically and critically within institutions, we provide our students with opportunities to recognize ways in which they can do so as well. There is no singular set of steps that will achieve the desired changes or calls for justice every time. But if students learn to be curious, creative, and resilient in their connections with each other, they will be well primed to make headway when they recognize injustice and can trace it back to the well-trodden ideologies that sexism, classism, and racism promote. 


\section{Works Cited}

Andzaldúa, G. (1987). Borderlands / la frontera: The new mestiza. San Francisco: CA: Aunt Lute Books.

Ahmed, S. (2017). Living a feminist Life. Durham, NC: Duke University Press.

Cannella, G. S. \& Koro-Ljungberg, M. (2017). Neoliberalism in higher education: Can we understand? Can we resist and survive? Can we become without neoliberalism? Cultural Studies $\rightarrow$ Critical Methodologies 17(3), pp. 155-162.

Crenshaw, Kimberlé (1989). "Demarginalizing the intersection of race and sex: A Black feminist critique of antidiscrimnation doctrine, feminist theory, and antiracist politics." University of Chicago Legal Forum: vol. 1989, article 8. Available at: https://chicagounbound.uchicago.edu/uclf/vol1989/iss $1 / 8 /$

Griffey, T. (2019, April 18). "What is the neoliberal university (or college), where did it come from, and what should be done about it? A Thread. [...]" Retrieved from https://threadreaderapp.com/thread/11190838894215 00419.html

hooks, b. (1994). Teaching to transgress: Education as the practice of freedom. New York: Routledge.

Imarisha, W. (2015). Introduction. In A. M. Brown \& W. Imarisha (Eds.), Octavia's Brood: Science fiction stories from social justice movements (pp. 3-5). Oakland, CA: AK Press.

Lorde, A. (1984). The master's tools will never dismantle the master's house. In Sister Outsider (pp. 110 - 113). Crossing Press.

Puwar, N. (2004). Space invaders: Race, gender and bodies out of place. London: Bloomsbury Academic.

Saunders, D. B. \& Ramirez, G. B. (2017). Resisting the neoliberalization of higher education: A challenge to commonsensical understandings of commodities and consumption. Cultural Studies $\leftrightarrow$ Critical Methodologies 17(3), pp. 189-196.

(cc)) BY-NC-ND

ULIS D-Sorke
This work is licensed under a Creative Commons Attribution-Noncommercial-No Derivative Works 3.0 United States License.

This journal is published by the University Library System of the University of Pittsburgh as part of its D-Scribe Digital Publishing Program, and is cosponsored by the University of Pittsburgh Press. 